\title{
A opinião pública distribuída: blogs e jornalismo nas Eleições Brasileiras de $2006^{1}$
}

\author{
Fábio Malini \\ Universidade Federal do Espírito Santo \\ fabiomalini@uol.com.br
}

\begin{abstract}
Resumo: Este estudo busca analisar o impacto da atividade discursiva dos blogs na campanha política brasileira de 2006, em particular, examinar como o regime de conversação e diálogo viral entre os autores dessas publicações online transformou o estatuto teórico da opinião pública (ligada à cultura de massa) e impulsionou a criação de um novo mercado do diálogo entre o jornalismo e as novas audiências online. Em 20o6, de posse de ferramentas de construção de redes sociais (principal o site de relacionamento Orkut), de ferramentas para publicações amadoras (os blogs, podcastings e wikis etc) e da criação de redes de debate por meio de listas e fóruns de discussão, os internautas militavam na defesa de seus candidatos a presidente, criando uma rede distribuída de informação totalmente baseada no contágio. Assim a opinião circula como uma praga, um vírus, num jogo infinito de "passa e repassa". Ela é, no ambiente das redes virtuais, uma opinião pública distribuída, algo tematizado e esmiuçado neste artigo.
\end{abstract}

Palavras-chave: Internet, Blogs e Jornalismo

Summary: This study search to analyze the impact of the discursive activity of the blogs in the Brazilian political campaign of 2006, in matter, to examine as the conversation regime and dialogue viral among the authors of those publications online transformed the theoretical statute of the public (linked to the mass culture) opinion and it impelled the creation of a new market of the dialogue between the journalism and the new audiences online. In 20o6, of ownership of tools of construction of social (main the relationship site Orkut) nets, of tools for amateur (the blogs, podcastings and wikis etc) publications and of the creation of debate nets through lists and discussion forums, the internautas militated in the defense of their candidates to president, creating a distributed net of information totally based on the contagion. Like this the opinion circulates as a curse, a virus, in an infinite game of "raisin and it reviews". It is, in the atmosphere of the virtual nets, a distributed public opinion, something it is analyzed in this article.

Key words: Internet, Blogs and Journalism

${ }^{1}$ Este trabalho, em sua versão mais aprimorada, foi apresentado como parte da minha tese de doutorado, defendida na Escola de Comunicação da UFRJ, sob a orientação de Henrique Antoun. 
Résumé: Ce étude objective analyser l'impact de l'activité discursive du blogs dans la campagne politique brésilienne de 2006, dans la matière, examiner comme le régime de la conversation et dialogue viraux parmi les auteurs de ces publications en ligne a transformé le statut théorique de l'opinion publique (lié à la culture de masse) et il a forcé la création d'un nouveau marché du dialogue entre le journalisme et les nouvelles audiences en ligne. Dans 2006, de propriété d'outils de construction de reseaux sociaux (principalment le site du rapport Orkut), d'outils pour les publications amatrices (le blogs, podcastings, wikis etecetera) et de la création de reseaux du débat à travers listes et forums de la discussion, les internautes ont milité dans la défense de leurs candidats à président, en créant un reseau distribué d'information totalement basé sur l'infection. Comme ceci l'opinion circule comme une malédiction, un virus, dans un jeu infini de "raisin sec et il examine". Elle est, dans l'atmosphère des reaseaux virtuels, une opinion publique distribuée, une theme que se examine dans cet article.

Mots-clés: Internet, Blogs, journalisme

Resumen: Este estudio busca analizar el impacto de la actividad divagadora de los blogs en la campaña política brasileña de 2006, en particular, examinar cuando el régimen de conversación y el diálogo viral entre los escritores de esas publicaciones en línea directa transformaron lo estatuto teórico de la opinión pública (ligada a la cultura masiva) y impelió la creación de un nuevo mercado del diálogo entre el periodismo y las nuevas audiencias en línea directa. En 2006, de la propiedad de herramientas de la construcción de redes sociales (principalmente el sitio de relación Orkut), de herramientas para publicaciones amadoras (los blogs, podcastings y wikis etc) y de la creación de redes de debate por listas y foros de discusión, los internautas incidieron a favor en la defensa de sus candidatos de presidente, creando una red distribuida de la información totalmente sobre la base de lo contagio. De este modo la opinión circula como una maldición, un virus, en un infinito partido de "Pasa y él repasan." Es, en lo ambiente de las redes virtuales, una opinión pública distribuida, algo analizado en este artículo.

Palabras-clave: Internet, blogs, periodismo

\section{Para além da opinião de massa}

No Brasil, todo sistema de pensamento sobre a formação da opinião pública se estilhaçou com a participação dos internautas durante o período das eleições majoritárias de 2006. A participação - principalmente em blogs, mas também em listas de discussão e email - acabou por curto-circuitar a matriz clássica do pensamento sobre a formação da opinião pública, sustentada em particular por dois modelos: o dos círculos concêntricos e o do líder de opinião, ambos são herdeiros das teorias sobre a cultura de massa. 
O modelo dos círculos concêntricos - ou a pedra no lago - sustenta-se na idéia de que há um centro formador e uma periferia reprodutora de opinião. Assim, quando o pólo central emite uma opinião, esta vai se espalhando pelas camadas até chegar os espaços sociais mais longínquos em relação ao centro emissor. A metáfora é que a opinião é produzida como uma pedra jogada num lago e impulsiona uma série de ondulações (na fórmula de círculos concêntricos) que seguem até às margens e são vistas até certo horizonte. Uma informação só teria o poder de espalhe se a mensagem for difundida a partir do centro emissor. Na prática, a formação da opinião pública está associada a um poder midiático (os meios de comunicação de massa) capaz então de gerar uma agenda pública.

Na prática, a formação da opinião pública significa um poder de influência nos sentidos que se valem as massas para formar os seus julgamentos sobre a vida pública. A lógica da pedra no lago sempre sustentava, por exemplo, que nas campanhas eleitorais a propagação da informação e de opiniões é mais sempre mais eficaz quando parte de um núcleo instruído (o setores médios que concentram os meios de difusão) vão disseminando-as para as classes sociais que estão nas franjas menos informadas ou com menor participação na gestão do jogo político. As bordas, portanto, teriam sempre a sua opinião pautada pelos pontos de vista de quem tem o poder midiático.

\section{Internet e a opinião pública distribuída}

Esse paradigma tradicional de opinião pública não serviu de referência para o entendimento de como se processou a conversação e o diálogo público em torno da agenda de opinião traçada pela sociedade brasileira sobre a corrida eleitoral a presidência em 2006. Isto, em parte, por um fenômeno absolutamente novo, a perda do oligopólio da opinião pelos veículos da imprensa do país e a forte participação dos internautas nas disputas sobre os sentidos das informações que circulavam sobre os seus candidatos. Essa participação fez nascer a prática da opinião pública distribuída.

A opinião tornava-se distribuída porque blogueiros republicavam as idéias uns dos outros; os subscritores ${ }^{2}$ enviavam uma informação de uma lista de discussão a outra para argumentar ou contra-argumentar; os orkuteiros criavam comunidades

$2 \quad$ Aqueles que participam (subscrevem-se) de listas de discussão. 
anti ou pró candidatos; leitores inundavam de textos a seção de comentários dos principais blogs jornalísticos para assim ganhar mais atenção na grande audiência desses veículos; internautas de sites como Youtube3, Dailymotion e Google Vídeo que hospedam e exibem vídeos, bem comentários sobre eles - assistiram e distribuíram entre seus blogs, listas de discussões e comunidades do Orkut, vídeos que zombavam dos candidatos. A famosa frase do presidente Lula - "alô, companheiros do Orkut!" 4 - legitima a influência da opinião em rede durante a corrida eleitoral.

No Orkut, a maior comunidade anti-Lula reunia 205 mil integrantes em outubro, enquanto a maior comunidade favorável ao presidente chegou a atingir 106 mil membros no mesmo período. Entre as 60 maiores comunidades de Lula, 34 eram negativas. Já dentre as 60 maiores comunidades de Alckmin, 21 eram negativas. A participação nesses espaços não se restringia apenas a "fazer parte". No dia de votação do segundo turno, foram registradas 30.575 postagens na comunidade "Nós votamos Lula Presidente 2006" e 54.803 mensagens em "Geraldo Alckmin Presidente 45". A força das comunidades on-line se aliou ao impacto dos vídeos que se propagaram na rede. No YouTube, um vídeo em que Alckmin interrompe uma entrevista a uma emissora de TV australiana após ser questionado sobre a quadrilha que atua nos presídios de São Paulo acumula quase 460 mil visualizações (Portal G1, online).

Acontece que a eleição brasileira foi um fato sociológico complexo porque, por um lado, o predomínio do discurso da chamada grande mídia foi reduzida pelas multiplicidades de mídias que faziam circulavam novas mensagens na web. De outro lado, ocorria uma forte resistência dos sujeitos circunscritos às franjas informacionais (em particular, os pobres), manifestada pela negação, pela desconfiança ou pelo desprezo pelo "poder midiático". O resultado foi que a opinião da grande mídia chegou mais intensamente aos círculos concêntricos mais próximos

3 O Youtube é o mais popular dos sites que permitem que usuários carreguem, assistem e compartilhem vídeos em formato digital. Seu nome vem do inglês you, você; e tube, tubo. Uma brincadeira para dizer que você pode construir a sua própria televisão. $\mathrm{O}$ site recebe diariamente uma média de 40 mil novos vídeos.

$4 \quad$ Num vídeo de 15 segundos, Lula pede votos durante o segundo turno: "Alô, companheiros que navegam pelo Orkut, muito obrigado pelo apoio de todas as comunidades. Vamos juntos continuar a construir um Brasil cada vez maior. No dia 29, vocês já sabem: votem 13". 
de si (as classes mais propensas a obter e gerar informação), mas o problema é que foram nestes mesmos círculos que ocorreram um fenômeno de ruptura formidável: a opinião distribuída. De posse de ferramentas de construção de redes sociais (principal o site de relacionamento Orkut), de produção amadora de publicações (os blogues, podcastings e wikis) e da criação de redes de debate por meio de listas de discussão, os internautas militavam na defesa de seus candidatos, criando uma rede distribuída de informação totalmente baseada no contágio. A opinião circula como uma praga, um vírus, num jogo infinito de "passa e repassa”.

O resultado dessa profusão de mídias online foi o aparecimento, em cada rede social, de novos formadores de opinião, que, em geral, obtinha esse título graças a sua insistência de publicar, muitas vezes diariamente, suas opiniões na forma de artigo, notas, comentários e vídeos. Cada um desses líderes encampava obrigatoriamente o protagonismo de alguma comunidade virtual. E, de forma curiosa, o líder de opinião de uma comunidade podia ser encontrado em outros espaços da internet sendo liderado por outros protagonistas da informação. No interior dessa polissemia de sentidos, a autoridade sobre a informação mostrou-se uma realidade imanente. O próprio usuário designava a hierarquia de relevância dos conteúdos, por meio basicamente de um processo, o número de links. Quanto mais links era direcionado a um blog (seja no positivo, ou negativo), maior seu poder de agendar a blogosfera, logo maior também seria a relevância da sua produção. A internet, como uma rede direcionada - como salienta Barabasi - trazia clusters diversificados que atuavam como referências no mundo da opinião em rede.

Durante a corrida eleitoral, o sistema Technorati, que examina a produção da blogosfera, identificou, somente entre os blogs, em língua portuguesa, cadastrados em sua base de dados, uma média de 300 post por dia sobre o candidato tucano Geraldo Alckmin, e cerca de 800 posts diários sobre o presidente Lula. Sistemas de busca focados em conteúdos de blogs, como o Google Blogs, registraram 21.000 posts referentes a Lula e 11.000 a Alckmin, entre 07 de julho a 30 de outubro, respectivamente início e fim da campanha. A média dos comentários nos principais blogs de jornalismo político, como o Blog do Noblat, foi de 500 comentários por entrada, quando o assunto dizia respeito à corrida eleitoral. Os comentários eram tão 
diversos, que muitas vezes a melhor informação era o debate travado pelos leitores na área de comentários em vez de o conteúdo jornalísticos (o post) que o originou.

No maior site de compartilhamento de vídeos, o Youtube, foram cerca de 900 vídeos tendo Lula como protagonista, e 500, Geraldo Alckmin. A natureza dos vídeos era a mais diversa possível: deboches, escárnio, documentários, testemunhos, flagras, programas partidários televisivos, discursos etc. $\mathrm{O}$ experiente jornalista e blogueiro Luis Nassif batizou o efeito dessa cornucópia de $o$ «fim do oligopólio da opinião»: “as eleições de 2006 marcam definitivamente o fim do poder absoluto da grande mídia sobre o mercado de opinião brasileiro" (Nassif, online). O centro desse fato estava principalmente na transformação dos blogs em ferramenta poderosa de mídia.

Gráficos 1 e 2 - Remissão das palavras Alckmin e Lula na blogosfera
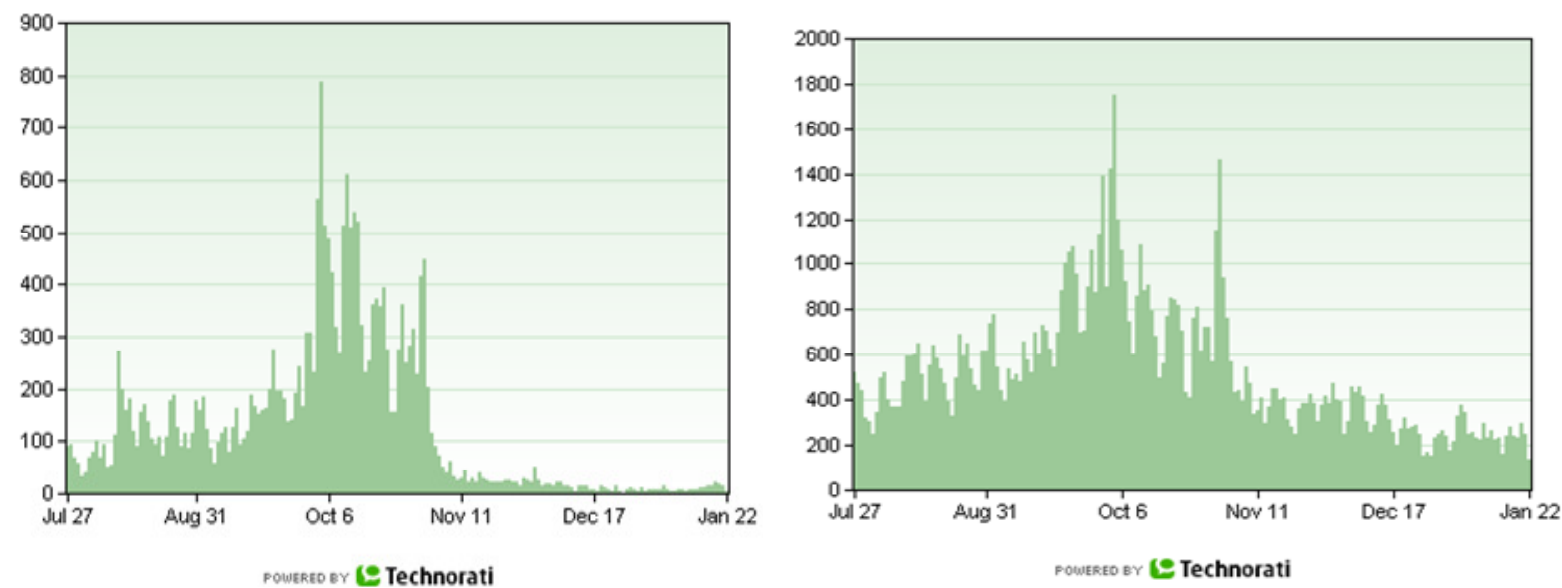

Todo esse arquivo de relatos na internet tornou-se a memória mais completa sobre as eleições de 2006. E resultou na criação de uma multiplicidade de blogs políticos. Após o fim as eleições, muitos desses blogs tornaram-se uma espécie de "observatório da política" brasileira, tendo uma pequena, mas cativa audiência. Mas, antes, seu principal papel principal foi de enterrar, de vez, a clássica teoria da comunicação a dois passos, que defendia que entre um veículo de comunicação e os indivíduos existiria a figura dos líderes de opinião, uma espécie de mediador com função de ativar, reforçar ou converter a opinião e a decisão dos indivíduos de seus grupos. "A noção de 'formador de opinião' aproximava-se da nossa tradição 
autoritária, na clássica fórmula de que, se o povo não sabe votar, alguém tem de ensinar. E que esse alguém existe, na figura da nossa elite, sempre pronta a dar a sua mão para ajudar o povo".

Em último caso, se os líderes de opinião não foram enterrados, ao menos seu o poder supremo foi um mito desfeito pelas urnas. 5 A comunicação colaborativa dos internautas fez com que a opinião se manifestasse através de uma rede distribuída de comunicação, sem a presença de qualquer intermediação, dado que os meios de produção acessível aos usuários permitiam-lhes a produção e reprodução de conteúdos, em distintas linguagens, sem a necessidade de conhecimentos específicos sobre a linguagem de programação da web, tampouco a orientação editorial de qualquer grupo de mídia. Os veículos dos mass media viram-se então imersos num plano em que o receptor penetrava no interior do newsmaking. Queria fazer parte do core do poder midiático. Foi uma verdadeira invasão bárbara pós-moderna cuja principal conseqüência foi a transformação das leis que regem o jornalismo contemporâneo, bem como na denúncia da "homogeneização da opinião, da redução do contraditório, da diminuição do espaço crítico" (Nassif, online) levado a cabo pelos grupos de mídia para favorecer certas candidaturas em detrimento de outras.

\section{O papel dos blogs nas eleições de 2006: análise da blogosfera lulista}

A blogosfera se dividiu de acordo com as preferências eleitorais do blogueiro. Havia aqueles que defendiam a candidatura Lula (os blogs lulistas), a de Geraldo Alckmin (os blogs alckmistas) e os que orbitavam em torno de um postura anti-tudo.

A blogosfera lulista emergiu como uma passeata virtual durante o episódio da chamada "lista de furnas" 6 , entre o final de 2005 e o começo de 2006. A lista era

$5 \quad$ O presidente Lula foi reeleito com mais de 58 milhões de votos, correspondente a $60,8 \%$ dos votos válidos.

6 A lista era um fotocópia de cinco folhas contendo uma lista de 156 políticos de 12 partidos (PDT, PFL, PL, PMDB, PP, PPS, Prona, PRTB, PSB, PSC, PSDB e PTB) que teria recebido dinheiro de caixa dois montado a partir da estatal federal de energia Furnas. $O$ valor das doações era de cerca de R $\$ 39,665$ milhões. Mais da metade desses recursos teria sido destinado à campanha de Geraldo Alckmin, José Serra e Aécio Neves, na campanha eleitoral de 2002. O restante teria sido rateado pelos outros políticos, entre eles, o deputado Roberto 
um documento que mostrava um esquema de caixa dois, organizado pelos políticos oposicionistas, na campanha de 2002. A lista circulou pela internet através do blogmanifesto Caixa Dois Tucano de Furnas, 7 mas logo foi desacreditada pela imprensa por conter erros e ter pouca consistência técnica. ${ }^{8}$ A imprensa nem sequer chegou a deslocar repórteres para checar a autenticidade do documento, que depois foi comprovada por um perito da Unicamp, algo também ignorado pela imprensa. 9

Mas o espalhe da informação na blogosfera chegou alcançar 60 posts ao dia, principalmente nos primeiros dois meses de 2006, segundo o Technoratio ${ }^{\circ}$. Cerca de 30 mil remissões do termo foram reproduzidos em blogs na web. Até comunidade no site de relacionamento Orkut ("eu acredito na lista de furnas") foi criada ${ }^{11}$. Um dos blogs lulistas, o Amigos do Presidente Lula, acabou se transformando em uma

Jefferson, que confessara ter recebido $\mathrm{R} \$ 75$ mil de Dimas Toledo, ex-diretor de Furnas, considerado o chefe do caixa dois.

$7 \quad$ A lista de Furnas foi exibida por Helena Sthephanowitz, no blog Caixa Dois Tucanos de Furnas (www.caixadoistucanodefurnas.blogspot.com/). Helena liderou o blog Amigos do Presidente Lula, (www.osamigosdopresidentelula.blogspot.com/), que alcançou a audiência de mais de um milhão de usuários. Acabou se transformando em um ícone da blogosfera lulista. Além disso, outros blogs tiveram importância e forma muito linkados pelos internautas. São eles: Tucanoduto (www.tucanoduto.blogspot.com/), Por um novo Brasil (www.porumnovobrasil.org/web/), Portal da Mídia petista (http://portalmidiapetista.blogspot.com/).

8 O colunista político da Folha Fernando Rodrigues foi logo enterrando o assunto, a partir do critério de objetividade jornalísticos: "Com os recursos disponíveis em informática, é possível alterar totalmente os papéis e imprimir novas cópias. Como são fotocópias, não há como provar qual foi o primeiro a ser montado. Mesmo que exista um original que tenha dado origem à autenticação das fotocópias --até porque um cartório no Rio atestou nesta semana ser verdadeiro o selo que está na cópia--, nada impede que o original também tenha sido montado. [...] Além dessas dúvidas técnicas, a "lista de Furnas" traz também erros factuais e inconsistências no que diz respeito à realidade política das pessoas citadas. [...] Os nomes de Luiz Paulo Velloso Lucas (ex-prefeito de Vitória, no Espírito Santo) e de Francisco Luiz Gomide (ex-ministro de Minas e Energia em 2002) aparecem como candidatos eleitos a deputado federal, mas nenhum dos dois chegou a se candidatar nas eleições de 2002". (Lista de Furnas tem erros e inconsistências. Folha Online. Disponível na internet: http://www1.folha.uol.com.br/folha/brasil/ultg6u75613.shtml

9 "O perito da Unicamp Ricardo Molina de Figueiredo teria feito a perícia de uma cópia do documento, formado por cinco folhas de papel com autenticação de cartório, em Outubro de 2005. O original, que poderia servir para dirimir algumas dúvidas, até o momento não apareceu. Molina disse que sua análise identificou o material como autêntico, contudo alertou que isto não significa que ele é verdadeiro, e que poderia ser até uma montagem feita com auxílio de um computador: "Se aquela informação que está ali é verdadeira ou não, isso é impossível saber por que qualquer um pode sentar numa máquina, no computador, fazer uma lista, assinar e mandar". (Wikinews. Disponível na internet: http://pt.wikinews.org/wiki/ Autenticidade da Lista de Furnas \%C3\%A9 questionada, acesso em 30/04/2006) ${ }_{10}^{10}$ http://technorati.com/chart/furnas? chartdays $=360$ \&language $=$ pt\&authority $=n$ http://www.orkut.com/Community.aspx?cmm=324.3603 
espécie de $h u b$, ao reunir as principais informações, debates e links para outros blogs que apoiavam a reeleição de Lula. O blog teve tanto acesso (100 mil acessos/dia), que sua autora, Helena Sthephanowitz, ${ }^{12}$ virou um ícone e formadora de opinião da rede lulista. Outro fato inusitado foi que o Amigos acabou sendo clonado ${ }^{13}$ por blogueiros adversários, que fizeram da interface do blog original objeto de sátira. Paralelamente aos conflitos na blogosfera, todos os grandes colunistas políticos ${ }^{14}$ com blogs online não publicaram a lista, mas tiveram de escrever uma nota sobre as suas opiniões sobre o documento, graças a uma pressão de internautas na seção de comentários, por email ou em seus próprios blogs, que ultrajavam o "silêncio dos jornalistas". ${ }^{15}$

12 Foi autora de um dos textos mais lidos na internet, o Peçonha Virtual, que duramente criticava colunistas e artistas (como Jô Soares) que se opuseram ao governo, por conta da crise do mensalão. $O$ texto circulou em 2580 sites da internet, transformando-se em outro meme da blogosfera lulista. Virulento e ácido, o texto se tornou uma espécie de purificação esquerdista: Estou de saco cheio de ver o único Governo em muitos anos que nos livrou do FMI, voltou a financiar moradias, criou um programa de segurança alimentar para atender os famintos, assumiu a liderança da América Latina e impôs respeito no mundo todo, ser execrado diariamente nos jornais, como se tivesse inventado a corrupção, a violência e todos os problemas que o país arrasta há quinhentos anos. (Peçonha Virtual. Amigos do Presidente. Disponível na internet: < http://amigosdo-presidentelula.blogspot.com/ >)

13 O endereço do clone: < http://amigosdopresidentelulla.blogspot.com/ >

14 O mais lido online, o Blog do Ricardo Noblat, opinou que não publicara a lista porque não se tinha certeza que ela era verdadeira: "Leitores reclamam do fato de este blog não ter publicado até aqui a lista dos políticos que supostamente teriam se beneficiado do caixa 2 de Furnas. [...] A história política brasileira está repleta de falsos documentos pelo menos dos anos 30 do século passado para cá. Durante mais de um ano, por exemplo, a mídia publicou notícias a respeito do Dossiê Cayman - uma suposta conta bancária no exterior onde políticos de peso teria depositado sobras de campanha. Descobriu-se depois que o Dossiê era falso. E que a conta jamais existira".

${ }_{15}$ "Noblat acreditava que a constituição foi escrita apenas para alguns poucos privilegiados, pois o tratamento que dispensa a outro partido claramente não é o mesmo. Quando Dirceu negou o mensalão, quando Lula negou conhecer o esquema e quando todos os aliados negaram e negam que existe o tal mensalão, mesmo antes das investigações, Noblat já falava em alto e bom som: "Mentira... os petistas só fazem mentir" ou seu sarcástico "então, tá". Melo, Gui. Blog do Noblat, a lista de Furnas. Blog Crítica da Notícia, de olho em Noblat e outros. Disponível na internet: http://deolhononoblat.blogspot.com/2006/02/ blog-donoblat-lista-de-furnas.html 
Gráficos 3 - Posts por dia sobre Lista de Furnas presentes na blogosfera (fevereiro 2006-janeiro 2007)

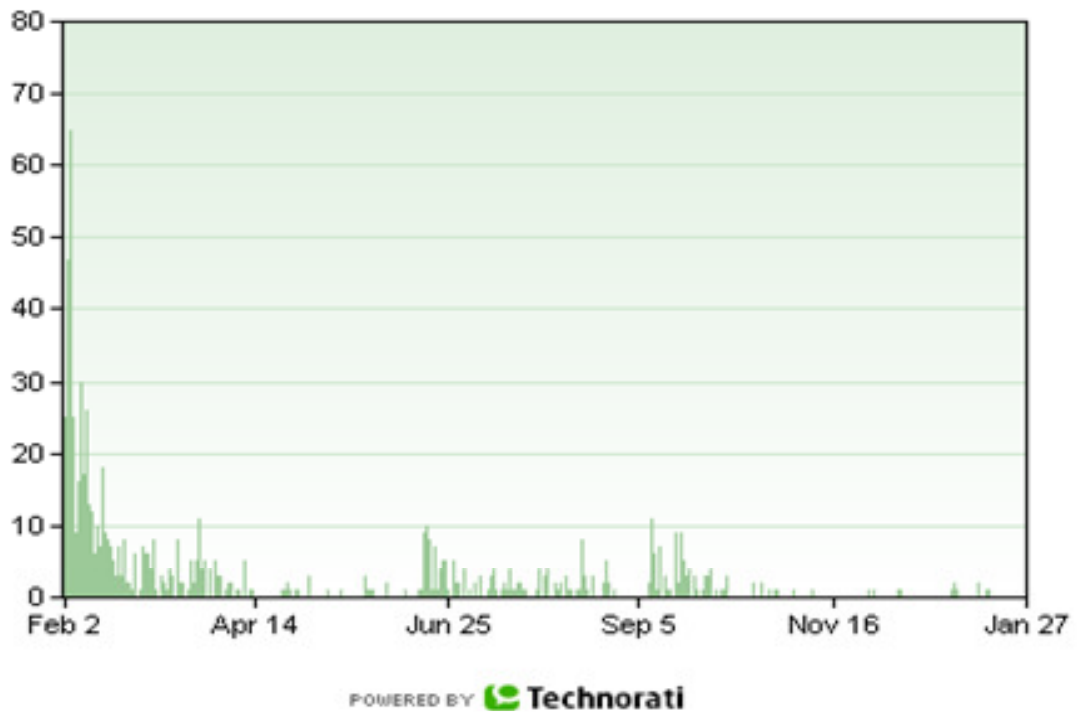

A repercussão acabou ecoando em Brasília. Deputados da chamada CPI do Mensalão convocaram o autor da lista, Dimas Toledo - que recebeu da Justiça o direito de se manter em silêncio -16 e encaminharam para peritos o exame do documento que circulava entre os blogs. Caciques da oposição se posicionaram, na imprensa, sobre a lista ${ }^{17}$. Os governistas elegeram o documento como tábua de salvação em meio ao fogo cruzado com os adversários. E, no meio da guerra política, a deputada federal do PSDB Zulaiê Cobra mostrou-se antenada ao relatar que a "lista de furnas" estava circulando desde 2005 num "blog chamado Amigos do Presidente"18. O senador Álvaro Dias - um dos oposicionistas mais fortes - também mandou o seu recado ao chargista Bira, reagindo a uma charge publicada no Amigos e disseminada na rede: "Senhor Bira, cabe a mim (sic) alertar que Vs. está

16 Em reportagem online, Segundo Zulaiê Cobra, a relação já estava sendo veiculada pela internet desde o ano passado, num blog chamado "amigos do Lula". A deputada acreditava que os donos do blog são os "pais" da lista, que está sendo investigada pela Polícia Federal.

$17 \quad$ Para o governador Geraldo Alckmin: "Investigar é sempre bom. Até porque, no caso da lista de Furnas, tem que ser descoberto os criminosos que fizeram isso. A Polícia Federal tem o dever de identificar os criminosos. Não é possível que não se consiga chegar à autoria dessa atividade criminosa. É dever elucidar o crime e apresentar para a sociedade os criminosos", disse.

18 "Os blogs são os pais da lista de Furnas". A frase foi dita pela deputada Zulaiê Costa (PSDB). Ver: Procuradoria investiga 'lista de Furnas'. Disponível na internet: http://www.camara.gov.br/INTERNET/ AGENCIA/materias.asp?pk=82882 
cometendo ato de difamação. Cabe ainda um alerta que usarei os recursos que a lei me permite para processar este antro que se diz blog que nada mais é que um bando de corruptos sem escrúpulos." 19

Os blogues lulistas acabaram por chegar ao coração do poder sem a intermediação da imprensa, que se calou sobre o acontecimento. A lista acabou por reforçar a opinião de que toda a política estava afundada em corrupção, ao mesmo tempo em que mostrava que a oposição só fazia perseguição política ao PT para alcançar eleitoralmente o presidente Lula. O espalhe da lista revelou-se assim parte das causas do acontecimento que os analistas na época chamaram de o renascimento de Lula, quando o presidente alcançou, pela primeira vez, o primeiro lugar nas sondagens de opinião, após meses amargando o segundo lugar, decorrente das sucessivas crises políticas que alcançavam o seu governo. Portanto, o presidente Lula renascia, em parte, pela elevação da temperatura criada pela blogosfera e repetida pelos políticos governistas em Brasília contra a reputação reivindicada pela oposição de portar a salvação ética para o país.

\section{Quando os blogs estendem o noticiário jornalístico}

A partir daí a blogosfera lulista se legitimou como watchblogs - "blogs que vasculham tudo o que sai publicado na imprensa sobre a campanha eleitoral", 20 ocupando um espaço de monitoramento diário sistemático da imprensa brasileira. Mas a blogosfera não se reduzia a um mero reflexo midiático. Ao contrário, reproduzia para reforçar sentidos não atribuídos pela imprensa. Para isso, articulavase em torno de textos, áudios, cartoons, vídeos, fotografias próprias, campanhas, testemunhos e artigos de publicações eletrônicas.

Devido ao elevado volume de material produzido, os blogs criaram gêneros textuais para classificar seus posts. Quando escreviam sobre algum político de oposição, então envolvido em corrupção no passado, mas que posava na mídia como defensor da moralidade, os blogueiros colocam uma gif com o dizer do tipo Fala sério! tem ladrão falando em corrupção. Assim o texto ficava inserido numa

\footnotetext{
19 Dias respondia ao cartunista Bira, do blog Amigos do Presidente Lula. Disponível na internet: http://osamigosdopresidentelula.blogspot.com/2006 0401 archive.html

20 Watchblogs surgiram na campanha de 2004 nos EUA. Ver Castilho, online
} 
campanha coletiva da blogosfera lulista. Outras campanhas foram realizadas, através de memes: "não ao golpe, eu voto em Lula”, "eu apóio o Lula”, “a inVEJA é uma merda", "CPI da mídia já”, "Sorria, você está sendo manipulado" etc. Quando a corrida eleitoral de fato esquentou, com a propaganda eleitoral televisiva, a blogosfera lulista continuou o espalhe de notícias e vídeos da campanha do presidente, além de reportar comícios, e investir numa campanha de associação de Alckmin com a ditadura ("eu abafei 69 cpi's") e com a privatização do patrimônio público. As três últimas campanhas juntas geraram mais de 60 mil remissões em sites e blogs na Internet, segundo o Google (a pesquisa pelo termo dobrou em relação a outros como mensalão ou sanguessuga). Na blogosfera, entre os blogs cadastrados no site Technorati, o assunto sobre privatização bateu a marca de 100 post/dia.

Gráficos 4 e 5 - Internautas produzem e consomem informações sobre "Privatização"
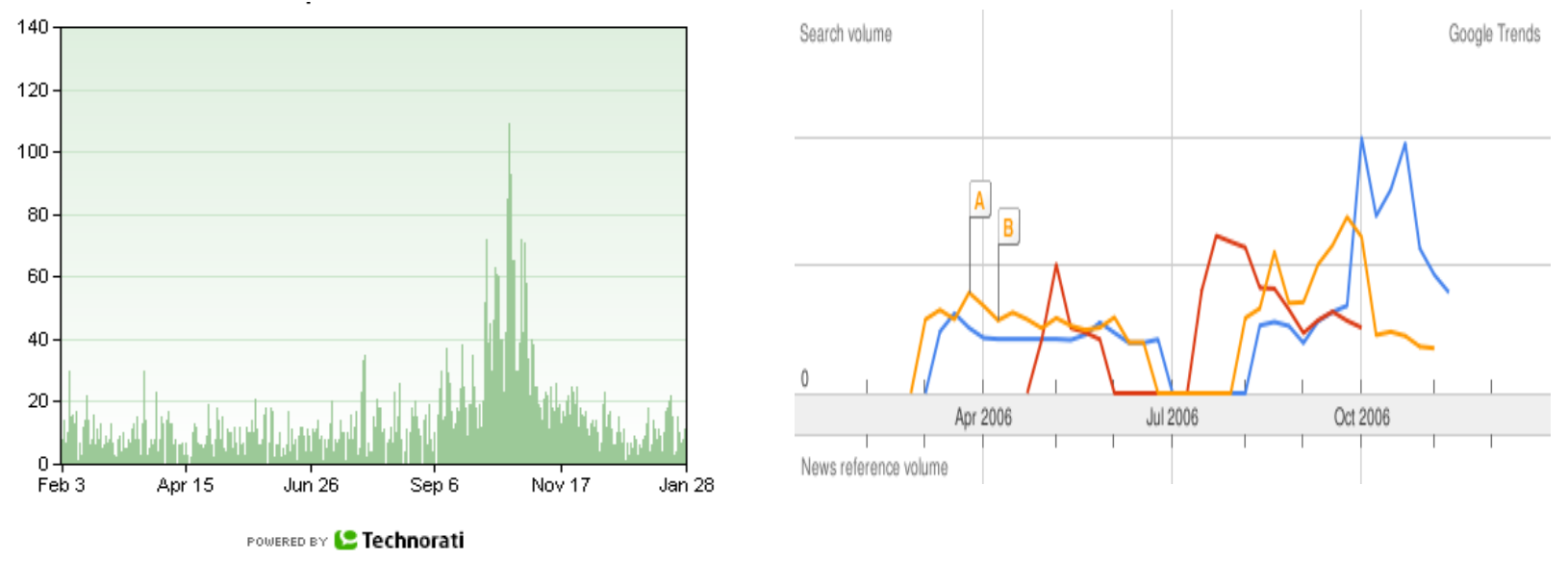

Essa "onda da opinião" acabou por manter todo o mês de outubro (o segundo turno das eleições) agendado pelo tema da privatização, pelo menos na Internet, o que, em termos eleitorais, acabou por reduzir a força política do candidato Geraldo Alckmin, então associado a uma imagem de privatista. Esse trabalho de agendamento acabou por forçar a imprensa a não encontrar um outro tema de pauta, a não ser às reações do candidato oposicionista, que demonstrava a cada evento uma atitude que desmentia, como ele mesmo dizia, o boato (buzz) que ele iria privatizar as principais empresas públicas brasileiras. Esse "boato" novamente era soprado - pela política viral da Web - para os outros veículos de comunicação, inclusive, para a 
blogosfera alckmista, que reagia publicando os benefícios da leva de privatizações impulsionadas no Governo de FHC. ${ }^{21}$

\section{O instante da anomalia}

As mídias colaborativas representam aquilo que o filósofo Antonio Negri denomina de poder constituinte, haja visto que os sujeitos que a produzem encarnam uma "força que irrompe, quebra, interrompe e desfaz todo equilíbrio preexistente e toda continuidade possível” 22 de uma estrutura midiática acostumada a tratar suas audiências através de um "espírito de rebanho" 23. Agora esse poder constituinte dos blogs só pode ser compreendido no interior de um processo de mutação social. E essa mutação, para Sodré24, vincula-se a uma revolução tecnológica e cultural cujo alcance antropológico pressupõe uma vida conectada e em rede, capaz de afetar toda a experiência humana de produção do real, em particular, o tempo, o espaço, a memória, corpo, o conhecimento, as identidades, as instituições e os valores sociais. "A rede dilui os poderes, ao mesmo tempo em que engendra uma nova forma de poder, o poder da rede, precisamente". 25

No contexto das eleições de 2006, esse "poder da rede" eclodiu quando, às vésperas da votação do primeiro turno, os principais veículos de mídia estampam uma foto do dinheiro que teria sido usado por integrantes do PT para pagar um possível (e falso) dossiê contendo denúncias contra o candidato tucano ao governo de São Paulo, José Serra. Dez dias depois a revista Carta Capital, publica uma matéria ${ }^{26}$ mostrando que a notícia das fotos do dinheiro nos meios impressos e no Jornal Nacional, da Rede Globo, fora orquestrado por então delegado da Polícia Federal

21 Já próximo do final das eleições, o jornalista Fernando Rodrigues escreveu no seu blog: “a campanha presidencial pegou fogo na web. Este blogueiro nunca recebeu tantos emails das correntes lulista e alckmista. O PT tem um volume muito maior e constante. O uso da Internet tem alcançado uma intensidade na política”. Os jornalistas-blogueiros foram constantemente alvo do ataquem em enxame da multidão da internet.

22 Sobre esse conceito, ver Negri, Antonio. O poder constituinte. Rio de Janeiro: DP\&A, 2002

23 Termo usado por Anderson, op cit, p.5

24 Sodré, Muniz. Um clique e uma revolução na notícia. Observatório da imprensa.

Disponível na internet:

$\underline{\text { http://observatorio.ultimosegundo.ig.com.br/artigos.asp?cod=338SAIoo1 }}$

$25 \quad$ Soriano, Paul in Sodré, op cit, online.

26 Pereira, Raimundo. Os fatos ocultos. Revista Carta Capital. Disponível na internet: http://www. cartacapital.com.br/edicoes/2006/10/415/5457/ 
Edmílson Pereira Bruno, que se encontrou clandestinamente com jornalistas do Estado de São Paulo, Folha de São Paulo, Rádio Jovem Pam e O Globo, exigindo que a imagem fosse veiculada no Jornal Nacional um dia antes dos jornais impressos ${ }^{27}$.

A foto foi tão valorizada pelo Jornal Nacional que o programa deixou de divulgar a notícia da queda do Boeing da Gol, que colidiu com um avião da Embraer, na região Centro-Oeste brasileira. Os principais jornais impressos do país imprimiram na primeira página $2 / 3$ do seu espaço repercutindo a divulgação das fotos, guardando uma dimensão minúscula ao desastre aéreo. $\mathrm{O}$ diretor de jornalismo da Rede Globo, Ali Kamel, responsável pelo jornal de maior audiência no país, teve acesso a um outro importante documento: um áudio da conversa do delegado com os jornalistas, gravado por um destes no exato momento da entrega as fotos para os repórteres.

Do ponto de vista jornalístico, o áudio revelava um delegado empenhado em fazer uso político das imagens - fato que foi ignorado por Kamel, que teria dito: "Não nos interessa ter essa fita. Para todos os efeitos, não a temos" 28. As sucessivas matérias de Carta Capital 29 provocaram um revés surpreendente na opinião pública. Uma avalanche de posts, comentários e troca de emails circulou pela internet. $\mathrm{Na}$ blogosfera, um média de 200 posts/dia, com um pico de 500 no auge das denúncias de Carta Capital, foi escrito sobre o tema, segundo o Technorati. No Google, houve

$27 \quad$ O delegado acabou sendo grampeado por um dos jornalistas na tal reunião clandestina. O áudio acabou sendo divulgado dias depois, graças a repercussão de matérias da Carta Capital na blogosfera: divulgar para uma tevê.

Delegado Bruno:- Agora é o seguinte, qual a televisão que eu divulgo? Eu preciso

Voz masculina de repórter:- Precisa sair numa tv... bom, na Globo ou no SBT...

Delegado Bruno:- Tem alguém da TV Globo aí?

Voz masculina de repórter: - tem o Bocardi, o Bocardi! [...]

né?

Voz masculina de repórter: - Só que é o seguinte: isso só pode sair amanhã na tv,

Delegado Bruno: - Não, pode sair hoje à noite na tv.[...] Padrão.

Delegado Bruno:Tem que sair no "Jornal Nacional". Se for o SBT, Ana Paula

(Portal G1. Leia e ouça, com nitidez e na íntegra, conversa do delegado do caso dossiê com repórteres. Disponível na internet:http://g1.globo.com/Noticias/Politica/o,AA1317305-5601,00.html

$28 \quad$ Pereira, op cit, online

29 As edições que trouxeram à luz da sociedade a tal tentativa de golpe foram as edições: de $\mathrm{n}^{0} 415$, de 14/10/2006, com o título da capa $A$ Trama que levou ao segundo turno; de $\mathrm{n}^{\mathrm{o}}$ 416, com o título de capa Contribuição ao dossiê da mídia. 
um surto de procura pelos termos Carta Capital e dossiê. "Em pouco tempo", analisou o jornalista e blogueiro Luis Nassif, "a matéria de Raimundo passava a repercutir em vários blogs. Os leitores passaram a descarregar a ira contra a encenação na parte de comentários”.30

Gráficos 6 e 7 - No Technorati, explode a remissão da palavra Carta Capital na blogosfera. De azul, termo Carta Capital alcança a mesma atenção da Revista Veja nos motores de busca do Google
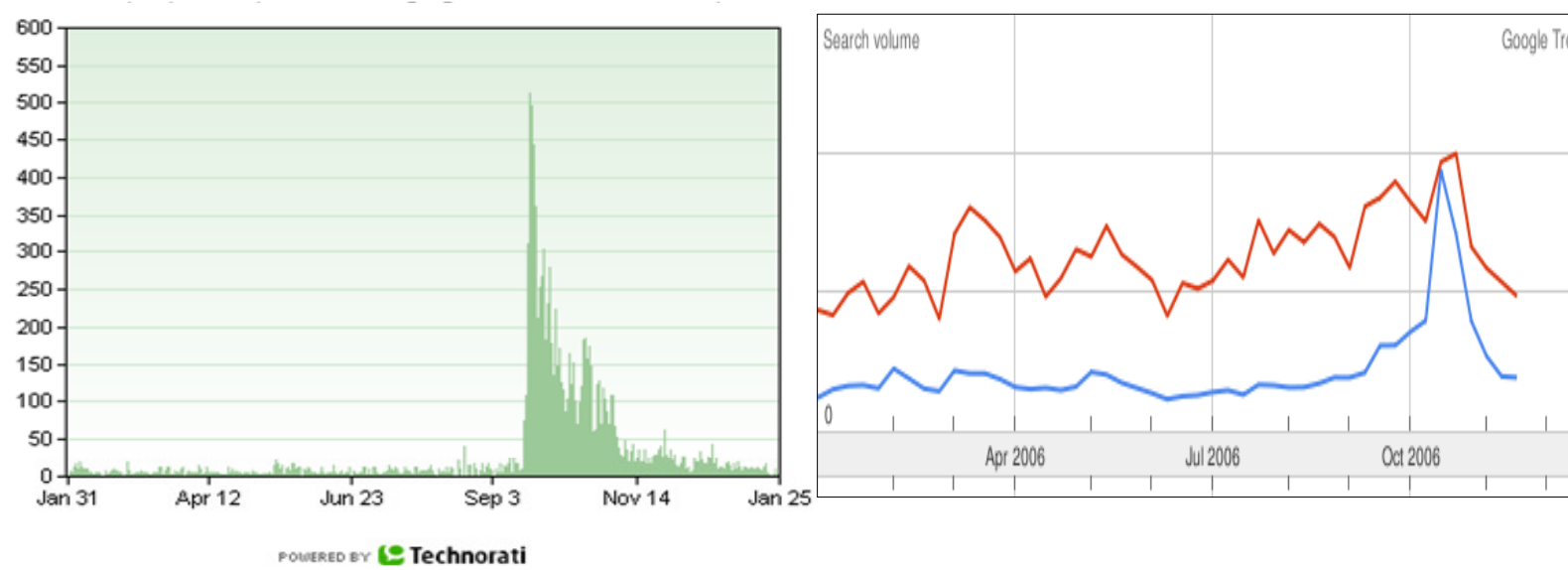

A reação desse movimento de produção singular de opinião foi rapidamente manifestada na imprensa online. Os internautas, movidos pela defesa das suas convicções ideológicas, produziram de forma massificada uma esfera de interlocução com outros usuários da web e com os próprios veículos da imprensa, gerando um amplo processo de conversação social, principalmente através das diferentes espécies da família blogs (diários virtuais, fotologs, videologs etc), como já analisamos. Toda essa diversidade do campo da opinião pública na internet começava ser metabolizado pelos blogueiros-jornalistas da grande imprensa, que tiveram que responder aos seus leitores como analisavam o conteúdo da revista Carta Capital.

Os blogs de grife se dividiram em contrários, favoráveis e reticentes ao que revelava a matéria da Carta Capital. Os reticentes ${ }^{31}$ foram aqueles que apenas publicaram o link da matéria da Carta, sem emitir qualquer opinião sobre o caso, quando muito tinha uma perspectiva ambígua: concordavam com a publicação da

\footnotetext{
3о Nassif, op cit, online

$31 \quad$ Blog da Teresa Cruvinel, Blog do Fernando Rodrigues, Blog do Noblat, foram aqueles que tomaram uma decisão de mais noticiar do que opinar sobre o "pega pra capar" entre Carta Capital e Globo.
} 
foto, mas condenavam a atitude dos veículos em não revelar os reais motivos do delegado em divulgar tal documento.

Ao trabalho: muita gente comentando a tal lista de Furnas. Não é verdade que não tenha dado atenção a ela, basta que leiam a coluna de hoje. E não vale me chamar de tucana (devo ser versátil, pois alguns me chamam de petista) pelo fato de ter apontado os indícios muito fortes de montagem ou manipulação dessa lista. Mas deve ser investigada, tudo deve ser investigado. Aliás, é isso que espero de quem investiga: jornalistas investigativos, polícias, cpis. Que nenhuma caixa dois seja perdoado. ${ }^{2}$

Já o grupo dos contrários 33 argumentava que a divulgação das "imagem da compra do dossiê" era um dever cívico do jornalismo, pois ser uma imagem sonegada da sociedade pelo governo. E que não havia motivação política na divulgação, mas esta foi produto de um "rancor humano", pois o delegado Bruno difundiu a fotografia para os jornalistas como uma resposta aos seus superiores em tê-lo retirado da investigação da compra do dossiê.

[...] Mas carimbar o episódio como um complô da mídia para prejudicar Lula é como atribuir ao termômetro a responsabilidade pela febre. Quem envenenou os planos do presidente foram os "aloprados" de seu partido, não os jornalistas. [...] não foi só a divulgação das fotos que produziu o segundo turno. $\mathrm{O}$ dossiêgate ganhara o noticiário havia duas semanas. A imagem da grana apenas deu ao escândalo a moldura que faltava. 34

Já o grupo dos favoráveis 35 defendia a tese de uma tentativa de golpe do estado e de uma campanha de difamação liderada pela imprensa contra o PT, algo que acontecia desde junho de 2005, com a chamada crise do mensalão. ${ }^{36}$ Para esses

\footnotetext{
$32 \quad$ Teresa Cruvinel, online

$33 \quad$ Blog do Josias de Souza, do UOL e todos os blogs da Veja Online.

$34 \quad$ Sousa, online

35 Blog do Mino Carta, Blog do Luis Nassif, Paulo Henrique Amorim, Blog da Teresa Cruvinel

36 "Escândalo do Mensalão ou "esquema de compra de votos de parlamentares" é o nome dado à maior crise política sofrida pelo governo brasileiro do presidente Luiz Inácio Lula da Silva (PT) em 2005/2006. O neologismo mensalão, popularizado pelo então deputado federal Roberto Jefferson em entrevista que deu ressonância nacional ao escândalo, é uma variante da palavra "mensalidade" usada para se referir a uma suposta "mesada" paga a deputados para votarem a favor de projetos de interesse do Poder Executivo. Segundo o deputado, o termo já era comum nos bastidores da política entre os parlamentares para designar essa prática ilegal.A palavra "mensalão" foi então adotada pela mídia para se referir ao caso. A primeira vez que a palavra foi grafada em um veículo de comunicação de grande reputação nacional ocorreu no jornal Folha de S.Paulo, na matéria do dia 6 de junho de 2005" (Wikipedia. Verbete Mensalão. Disponível na internet:
} 
blogueiros o grande erro da imprensa era forçar certa imparcialidade jornalística, já que, na prática, a decisão em publicar a fotografia com maior destaque que o acidente aéreo mostrava o lado oposicionista da grande mídia.

Um golpe de Estado levou a eleição para o segundo turno.É o que demonstra de forma irrefutável a reportagem de capa da revista Carta Capital que está nas bancas. ${ }^{37}$

[...] qual o interesse jornalístico de uma foto? Uma foto de dinheiro é igual a uma foto de dinheiro. Não há informação nisso. Essa foto ainda foi maquiada para dar maior fotogenia. $\mathrm{O}$ único interesse era como ela ia repercutir nas eleições, como no caso da Roseana Sarney. A gente sabia que esse dinheiro existia há semanas. O fato de aparecer a foto não tem significado nenhum. Mas os jornais e TVs queriam dar a imagem para saber o efeito eleitoral da foto. Se o único interesse sobre a foto era esse, é evidente que a parte mais relevante do ponto de vista da notícia era saber como vazou a foto. E não deram isso. Manipularam e protegeram o delegado (Edmilson Bruno Pereira). Isso é um episódio marcante. Um golpe como esse, não temos paralelo em nossa história. A mídia, cumprindo esse papel, é suicida. ${ }^{38}$

A repercussão da avalanche de comentários nos blogs jornalísticos e dos artigos na blogosfera acabou forçando Ali Kamel a enviar uma resposta ${ }^{39}$ para o site Observatório da Imprensa $4^{\circ}$, o blog do ex-global Paulo Henrique Amorim e à própria Carta..$^{11} \mathrm{O}$ coração da indústria jornalística - o responsável pelo telejornal de maior audiência brasileiro - entrava na agenda dos veículos participativos da

http://pt.wikipedia.org/wiki/Esc\%C3\%A2ndalo do mensal\%C3\%A3o acesso em 12/05/2006).

$37 \quad$ Amorim, online

$38 \quad$ Nassif, op cit, online

39 Kamel defendeu-se ao alegar que:o JN não divulgou a queda do Boeing da Gol, porque a primeira notícia sobre o fato surgiu no Portal Terra às $20 \mathrm{~h} 46 \mathrm{~min}$ (http://noticias.terra.com.br/brasil/interna/o,,OI1166661-EI306,oo.html) e ainda nãooficial. A Carta Capital havia publicado que a primeira informação sobre o acidente havia sido circulada na Internet às $18 \mathrm{~h} 35$; Negou que havia tomado conhecimento de fita que continha conversa do delegado com os jornalistas; Reforçou que publicou as fotos do dinheiro porque eram de interesse público; Disse que o delegado não havia privilegiado o JN, mas todos os outros veículos jornalísticos da TV.

$40 \quad$ Seu principal editor, Alberto Dines, foi taxado pelos internautas de aliado de Kamel na luta contra a blogosfera lulista. Nunca como antes Dines viu sua reputação ser colocada em cheque. Recebeu mais de 2.000 comentários em menos de uma semana, na maior parte longos e críticos, sobre o seu posicionamento de "defesa a imprensa" no caso .

$41 \quad$ Kamel teve que pagar a CartaCapital pelo espaço ocupado pela sua resposta, pois se recusou a escrevê-la com 13 mil caracteres, espaço que a revista o oferecia gratuitamente. 
internet, que, com sua capacidade de produzir buzz - burburinhos e boatos enterrou a reputação de objetividade da imprensa nacional. ${ }^{42}$

Ao analisar o fenômeno participativo dos watchblogs, Carlos Castilho, em seu blog Código Aberto43, no Observatório da Imprensa, argumentava que a emergência do "leitor patrulheiro assusta os editores", ao se referir ao trabalho diário de internautas 44 que entupiam a caixa de email e a seção comentários dos jornais e blogs jornalísticos online, e assim provocar o descrédito das opiniões desses editores.

O patrulhamento rompe, pela primeira vez na história da imprensa, com a tradicional unidirecionalidade do fluxo informativo. Até agora, quase toda a informação fluía dos tomadores de decisões e formadores de opinião, através dos jornalistas, até o público, cujo poder de retro alimentar o circuito informativo era muito limitado. O rompimento ocorre em circunstâncias traumáticas, especialmente para os jornalistas, que passam a se sentirem encurralados e hostilizados por uma massa de leitores que estraçalha reportagens e comentários com um ímpeto também inédito na história do jornalismo brasileiro. Quem lê os comentários postados em weblogs e páginas políticas online percebe rapidamente que a esmagadora maioria dos comentários revela uma atitude ácida em relação à imprensa. A argumentação quase sempre responde ao impulso e à paixão, o que provoca ressentimentos dos patrulhados. ${ }^{45}$

\section{Considerações finais}

A participação dos usuários, principalmente em blogs, apontou que a internet tornava-se a aliada mais forte à radicalização democrática da comunicação no país, tão espremida entre duas formas hegemônicas de poder: a forma-Estado e a forma-Globo. A forma-Estado conseguiu, desde o século passado, estabelecer regras e normas de concessões públicas de radiodifusão que foram responsáveis pela

42 A onda de manipulação global se espalhou tanto que 172 jornalistas assinaram um manifesto contra "insistente tentativa de atingir nossa honra e nossa correção profissional por alguns supostos colegas nestes dias que antecedem o encerramento das eleições 2006". (Sobre o manifesto, ver Observatório da Imprensa. Disponível na internet:

http://observatorio.ultimosegundo.ig.com.br/artigos.asp?cod=404IMQo04

43 http://observatorio.ultimosegundo.ig.com.br/blogs.asp?id blog=2

$44 \quad$ Nos EUA, esses internautas foram apelidados de "jornalistas de pijama" pelo trabalho de ficar 24 horas monitorando e checando se as informações divulgadas na mídia sobre seus candidatos procediam ou eram manipuladas.

45 Castilho, Carlos. O leitor patrulheiro assusta os editores. Blog Código Aberto.

Disponível na internet:

http://observatorio.ultimosegundo.ig.com.br/blogs.asp?id blog=2\&id=\%7BD34FD721-

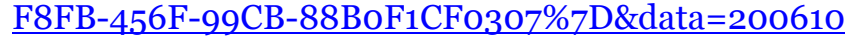


formação e a consolidação dos grandes conglomerados da mídia eletrônica cujos atores, os barões da mídia, eram protagonizados por famílias que concentram de forma horizontal, vertical e cruzada os meios de comunicação social. Quando a Constituição Brasileira de 88 promulgou o impedimento de qualquer forma de concentração de mídia, o estrago já tinha sido feito, a mídia eletrônica já estava toda rateada para a elite política e econômica brasileira. O grande legado do Estado foi ter inventado a oligarquia privada (forma-Globo) e a "oligarquia estatal" (a formaEstado). No final da contas, sempre estivemos dentro de uma coisa só: uma estratégia do poder de nos fazer passivo à produção discursiva dos meios de comunicação.

A anomalia dos blogs nas eleições de 2006 deu às forças sociais a possibilidade de exigir a construção de um mercado de opinião estruturado através do "poder das fontes livres". Portanto, a novidade do cenário eleitoral foi a emergência da política das bordas. O revés da opinião abriu um novo ciclo de lutas materiais que se respalda na busca pela universalização das tecnologias digitais como condições primárias para que a toda a sociedade possa ser produtora de comunicação. O conflito se abre contra a forma-Estado. Contra a forma de reger o mercado de comunicação, organizado em torno de uma concentração de poder em que a liberdade de expressão é ação inclui somente de forma abstrata os atores sociais no mercado de mídia - a legislação possibilita ter canais de TV e rádio a quem quer que deseje, mas isso acaba por excluir concretamente todos, já que não há condições estruturadas para que as bordas possam produzir seus próprios meios de comunicação.

\section{$\square$ Referências bibliográficas}

NEGRI, Antonio. O poder constituinte. Rio de Janeiro: DP\&A, 2002

BLOOD, Rebecca. (2002). O Livro de Bolso do Weblogue. Lisboa: Campo das Letras, 2006

CASTELLS, Manuel. A Galáxia Internet - reflexões sobre a Internet, os negócios e a sociedade. São Paulo: Jorge Zahar, 2005..

GILMOR, Dan. Nós, os media. Lisboa: Editorial Presença, 2005

GRANIERI, Giuseppe. Geração Blogue. Lisboa: 2006

MALINI, Fabio. O Comunismo das Redes: sistema midiático p2p, colaboração em rede e novas políticas de comunicação em rede. Tese de Doutorado. Rio de 
Janeiro, Escola de Comunicação. Universidade Federal do Rio de Janeiro. 2007. $350 \mathrm{pp}$.

RHEINGOLD, Howard. Multitudes Inteligentes: la proxima revolución social. Barcelona: Gedisa, 2004

\section{Documentos na Internet}

AMORIM, Paulo Henrique. $01^{\circ}$ Golpe já houve. E o $2^{\circ}$ ? Conversa fiada, Blog de Paulo Henrique Amorim. Disponível na internet: < http://conversaafiada.ig.com.br/materias/394501-39500o/394778/394778_1.html >

CASTILHO, Carlos. Watchblogs, a nova patrulha da imprensa. Disponível na internet: http://observatorio.ultimosegundo.ig.com.br/artigos.asp?cod= 265ENOoO1

COIMBRA, Marcos. Senhores de si mesmo. Revista Carta Capital. São Paulo: ano XIII, $\mathrm{n}^{0}$ 425, 27 de dezembro de 2006, pp 20-24.

CRUVINEL, Teresa. Abrindo a caixa de ferramentas. Disponível na internet: < http://oglobo. globo.com/blogs/tereza/default.asp?a=13\&periodo=200602 > Acessada em 22/01/2006

FOLHA ONLINE. Lista de Furnas tem erros e inconsistências. Disponível na internet: http://www1.folha. uol.com.br/folha/brasil/ult96u75613.shtml< Acessada em 22/01/2006 >

NASSIF, Luís. O fim do oligopólio da opinião. Blog do Nassif. Disponível na internet: <http://luisnassif.blig.ig.com.br/ > acesso em 25 de janeiro de 2007

PEREIRA, Raimundo. Os fatos ocultos. Revista Carta Capital. Disponível na internet: http://www. cartacapital.com.br/edicoes/2006/10/415/5457/ < Acessada em 22/01/2006 >

PORTA G1. Eleições mobilizaram 1 milhão no Orkut, diz pesquisa. http://g1.globo.com/Noticias/Politica/o,,AA1395343-5601-23,oo.html < Acessada em 22/01/2006 >

Leia e ouça, com nitidez e na íntegra, conversa do delegado do caso dossiê com repórteres. Disponível na internet:

http://g1.globo.com/Noticias/Politica/o,„AA1317305-5601,oo.htm < Acessada em 22/01/2006 >

Internet serviu para ridicularizar candidatos. Disponível na internet: http://g1.globo.com/Noticias/Politica/o,,AA1395362-5601,oo.html $<$ Acessada em 22/01/2006 >

SODRÉ, Muniz. Um clique e uma revolução na notícia. Observatório da imprensa. Disponível na internet:

http://observatorio.ultimosegundo.ig.com.br/artigos.asp?cod=338SAIoo1

SOUSA, Josias. Escorado em revista, PT renuncia complô da mídia. Blog do Josias de Sousa. Disponível na internet:

http://josiasdesouza.folha.blog.uol.com.br/arch2006-10-08_2006-1014.html 


\section{Sites Consultados:}

http://luisnassif.blig.ig.com.br/

http://josiasdesouza.folha.blog.uol.com.br/

www.caixadoistucanodefurnas.blogspot.com/

www.osamigosdopresidentelula.blogspot.com/

www.tucanoduto.blogspot.com/

www.porumnovobrasil.org/web/

http://portalmidiapetista.blogspot.com/

http://technorati.com/

http://www.orkut.com

http://amigosdopresidentelulla.blogspot.com/

http://deolhononoblat.blogspot.com/

http://oglobo. globo.com/blogs/tereza/

http://observatorio.ultimosegundo.ig.com.br/

http://www1.folha. uol.com.br/

http://g1.globo.com/

http://pt.wikipedia.org/

http://conversa-afiada.ig.com.br/ 